\title{
ВПЛИВ АЗОТНОГО ЖИВЛЕННЯ І ЗАХИСТУ ПОСІВІВ ВІД БУР'ЯНІВ НА ПРОДУКТИВНІСТЬ СОЇ В ПРАВОБЕРЕЖНОМУ ЛІСОСТЕПУ УКРАЇНИ
}

В. М. ЖЕРЕБКО, доктор сільськогосподарських наук, професор*

ORCID 0000-0001-9988-1837

О. В. ДИКУН, аспірант*

ORCID 0000-0001-8378-8646

М. О. ДикУН, провідний інженер **

ORCID 0000-0003-4187-0865

* Національний університет біоресурсів і природокористування України

** Iнститут фізіології рослин і генетики НАН України

E-mail: Allasaker823@gmail.com

Анотація. У статті проаналізовано результати дворічних досліджень сумісного впливухімічного захиступосівів від бур'янів, азотнихмінеральнихдобрив та інокуляції посівного матеріалу на продуктивність та якість урожаю сої в Правобережному Лісостепу України.

Польові досліди впродовж 2017 - 2018 рр. проводили в стаціонарній сівозміні лабораторії селекціі та насінництва відокремленого підрозділу НУБіП України «Агрономічнадосліднастаниія» вселі Пшеничне Васильківського району Київськоїобласті.

Встановлено, що за умов змішаного типу забур'янення високу технічну ефрективність забезпечували бакові суміші гербіцидів; як грунтових - Зенкор (0,4 л) га) + Комманд (0,2 л/га), так і післясходових - Базагран (2,5 л/га) + Хармоні (0,008 кг) га). У вказаних дозах двокомпонентні гербіцидні суміші знижували сумарну кількість однодольних та дводольних бур'янів на 30 день після внесення на 41-78 \%, а перед збиранням - на 61-67\%, а сиру масу всіх бур'янів зменшували майже на $80 \%$.

Відмічено, що ефективне контролювання забур'яненості посівів сумішшю препаратів Зенкору і Комманду, попередня інокуляція та внесення азотних мінеральних добрив у дозі N9O сприяли підвищенню продуктивності культури та формуванню більш високого врожаю. Достовірна прибавка його по відношенню до контролю без інокулячії, добрив та хімічних прополювань склала на цих варіантах

* Науковий керівник - доктор сільськогосподарських наук, професор В. М. Жеребко 
майже $3 \mathrm{~m} / 2 а$ або близько 300 \%. Водночас не виявлено негативного впливу ендогенного мінерального азоту та гербіцидного фону на процеси біологічної азоторіксації в грунті.

Результати досліджень свідчать про позитивний вплив раціонального застосування вказаних агротехнічних прийомів на покращення якості врожаю сої, зокрема на збільшення вмісту білка в зерні на 6,4 \%.

Ключові слова: соя, грунтові та післясходові гербіциди, технічна ефективність, бакові суміші, інокуляція, азотні добрива, ефективність застосування

\section{Актуальність.}

Соя є цінною харчовою, кормовою та технічною культурою, потужним продуцентом рослинного білка та олії, завдяки чому стрімко розширюються іiі посівні площі в світі й, зокрема, в Україні. Однак іï урожайність залишається низькою через значну забур'яненість посівів, що може призводити до втрати 75 \% потенціального врожаю (Гутянський Р. А., 2013). Проблему надійного контролю всього комплексу бур'янів у посівах сої можна вирішити лише за допомогою ефективних і високоселективних гербіцидів, що характеризуються низькою фітотоксичністю як щодо сої, так до грунтової мікрофлори (у т. ч. бульбочкових бактерій) та незначним впливом на довкілля (Гуральчук Ж. 3., Сорокіна С. І., Родзевич О. П., Мордерер С. Ю., 2012; Жеребко В. М., Жеребко Ю. В., Чернега Т. А., 2000; Жеребко В. М., 2015). Окрім належного захисту від бур'янів, формування високого біологічного врожаю неможливе й без оптимізації грунтового живлення культури, важливою складовою якого $є$ властива сої симбіотична азотфіксація, що на 50-70 \% забезпечує потреби рослин в азотних сполуках (Рекомендации по применению Ризоторфина, 1978).
У той же час соя позитивно реагує на додатковий мінеральний азот, що значно підвищує продуктивність рослин. За високих доз мінеральний азот може негативно впливати на формування й функціонування бобово-ризобіального симбіозу та у значній мірі нівелювати ефект штучної інокуляції посівного матеріалу активними штамами ризобіїв (Даценко В. К., Маліченко С. М., Береговенко С. К., Коць С. Я., 2003). У зв’язку з цим, актуальними і важливими є питання сумісного використання перспективних гербіцидів, азотних мінеральних добрив та штучної інокуляції задля отримання максимальної продуктивності посівів.

\section{Аналіз останніх досліджень та публікацій.}

Підвищення врожайності та покращення якості насіння сої неможливе без впровадження новітніх агробіологічних технологій іiі вирощування, що включають ефективний захист від бур'янів та раціональне використання добрив (Гуральчук Ж.З., Сорокіна С. І., Родзевич О. П., Мордерер С. Ю., 2012).

3 метою ефективного контролювання забур'яненості в посівах сої важливе не лише впровадження но- 
вих перспективних гербіцидів, а й пошук нових прогресивних методів їхнього застосування. Ряд наукових досліджень (Шепілова Т. П., 2016; Гутянський Р. А., 2008) та практика передових господарств засвідчують необхідність використання як грунтових, так і післясходових гербіцидів. Високоефективними виявились бакові суміші різноманітних препаратів, що розширюють спектр впливу на бур'яни, створюють композиції синергічного впливу, істотно зменшують резистентну стійкість бур'янів до окремих препаратів (Гутянський Р. А., 2013).

У разі застосування грунтових гербіцидів, які представлені високоактивними сполуками та здійснюють фізіологічну дію як на процеси метаболізму рослин, так і на бульбочкові бактерії, можливий негативний вплив на формування й функціонування азотфіксуючого симбіозу (Пищур I. М., Канівець В. І., Ларченко I. B., 2014).

Питання необхідності та раціонального застосування азотних мінеральних добрив у посівах сої дотепер залишаються дискусійними. Значно підвищуючи продуктивність рослин, вони за високих доз внесення можуть негативно впливати на процеси симбіотичної азотфіксації й накопичення в грунті біологічного азоту (Даценко В. К., Маліченко С. М., Береговенко С. К., Коць С. Я, 2001; Кулик М. Ф., Жмудь О. В., Бабич А. О., Засуха Т. В., Обертюх Ю. В., Кулик Я. М, Зелінська Н. В., 2010).

Мета дослідження - вивчення впливу ефективності застосування азотних мінеральних добрив та інокуляції на врожайність та якість зерна сої за умови застосування грунтових та післясходових гербіцидів.

\section{Матеріали і методи досліджень.}

Польові досліди (2017 - 2018 рр.) були закладені в стаціонарній сівозміні лабораторії селекції та насінництва Агрономічної дослідної станції НУБіП України в с. Пшеничне Васильківського району Київської області. Грунт - чорнозем глибокий малогумусний середньосуглинковий, із вмістом гумусу 4,43\% (за Тюріним), pH сольової витяжки - 6,1-7,0, ємність поглинання - 319 мг-екв на 1 кг грунту, вміст легкогідролізованого азоту (за Корнфільдом) - 106-114 мг/1 кг.

Погодні умови двох років спостережень суттєво відрізнялись. У 2017 році вегетаційний період був досить спекотним і посушливим, а наступний - більш прохолодним та дощовим із середньорічною кількістю опадів 560 мм, що на 130 мм більше попереднього року. Оптимальні умови 2018 року забезпечили високу продуктивність рослин сої (до 6 т/га) та збір зерна високої якості із середнім умістом протеїну біля $40 \%$.

Агротехніка в дослідах - загальноприйнята для зони Лісостепу, за винятком агрозаходів, які досліджували. Азотні мінеральні добрива у вигляді аміачної селітри (N - 34 \%) вносили згідно схеми досліду за кілька днів до сівби, а інокуляцію посівного матеріалу - в день сівби сухим інокулянтом «Хай Стік соя» німецької фірми БАСФ. Гербіциди вносили за допомогою ранцевого акумуляторного оприскувача «Фореста»; грунтові - за 5-7 днів після сівби, заробляючи їх у грунт легкими боронами, а післясходові - 3 появою третього справжнього листка. Сою сорту Медісон висівали в першій декаді травня зерновою сівалкою Great Plains 
3P606NT iз шириною захвату 1,8 м із розрахунку 600-700 тис рослин на 1 га. Облікова площа ділянок - $25 \mathrm{~m}^{2}$, повторність - три- та чотириразова.

Облік забур'яненості проводили кількісним та кількісно-ваговим методами через 30 днів після внесення гербіцидів та перед збиранням врожаю 3 врахуванням видового складу бур'янів.

В якості порівняльних у схему досліду було включено 2 контролі - (контроль 1 - без хімічних і механічних прополювань, контроль 2 - із двома ручними прополюваннями).

Вплив азотного живлення визначався на варіантах із штучною інокуляцією та додатковим мінеральним азотом у дозі $\mathrm{N}_{90}$.

Облік урожайності сої проводили методом відбору пробних снопів із частини кожної облікової ділянки 3 подальшим ручним обмолотом та перерахуванням отриманого врожаю на 1 га.

Біохімічну якість зерна визначали за допомогою інфрачервоного аналізатора «Інфраматик 8600» від швейцарської фірми «Perten».

У досліді вивчалася технічна й господарська ефективність таких гербіцидів:

- грунтових - Примекстра TZ-Голд $(31,25 \%$ S-метолахлору $+18,75 \%$ тербутилазину, к. с., 4,5 л/га) та бакова суміш Зенкору (70 \% метрибузину, к. с., 0,4 л/га) і Комманду (48 \% кломазону, к. е., 0,2 л/га);

- післясходових - бакова суміш Базаграну (48 \% бентазону, в. р., 2,5 л/га) і Хармоні (75 \% тифенсульфурон-метилу, в. р. гр., 0,008 кг/га).

\section{Результати дослідження та їх обговорення.}

За роки досліджень на дослідних полях відмічений середній рівень забур'яненості, що на контролях без прополю- вань складав 70-80 шт./м² (табл. 1).

Характерним був змішаний тип забур'янення з невеликою перевагою дводольних малорічних бур'янів над однорічними злаками. Кількість багаторічних бур'янів була значно меншою (близько 3,2 шт./м²) і суттєво не впливала на ріст і розвиток рослин.

Через 30 днів після застосування гербіцидів відмічене значне (41-78\%) зниження забур' яненості на всіх варіантах. Бакові суміші і грунтових, і післясходових гербіцидів відрізнялись більшою технічною ефективністю стосовно всіх груп бур'янів, знищували до 80 \% наявних бур'янів, що близько до контролю з ручними прополюваннями. Високу активність зафіксовано на варіантах із застосуванням гербіциду Примекстра TZ-Голд. Однак препарат ефективно знищував лише однорічні злакові бур'яни (на 82-84 \%), поступаючись іншим препаратам щодо дводольних малорічників. Помітною була фітотоксична дія на рослини сої: суттєво сповільнювався їхній ріст, що в подальшому призводило до недобору врожаю. Дещо пригнічувала рослини і бакова суміш Базаграну й Хармоні, викликаючи характерні жовтуваті плями на листках, але істотно не впливала на продуктивність культури. Рівень азотного живлення не впливав на ефективність дії гербіцидів.

Облік забур'янення перед збиранням урожаю підтвердив високу технічну ефективність бакових гербіцидних сумішей (табл. 2).

Вища загибель бур'янів відмічена за внесення суміші грунтових препаратів Зенкору й Комманду, де вона була близькою до 70 \%. Дещо нижчий показник був за бакової суміші Базаграну й Хармоні, де загибель склала 61-65 \%, а також грунтового гербіциду Примекстра TZ-Голд (63-79 \%).

Важливим показником ефективнос- 
1. Ефективність захисту посівів сої від забур'янення через 30 днів після внесення гербіцидів (середнє за 2017 - 2018 рр.)

\begin{tabular}{|c|c|c|c|c|c|}
\hline \multirow{3}{*}{ 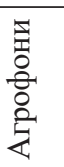 } & \multirow{3}{*}{ Варіанти застосування гербіцидів } & \multicolumn{4}{|c|}{ Загибель бур'янів, \% } \\
\hline & & \multirow{2}{*}{$\begin{array}{l}\text { Всього } \\
\text { бур'янів }\end{array}$} & \multicolumn{2}{|c|}{ однорічних } & \multirow{2}{*}{$\begin{array}{l}\text { багато- } \\
\text { річних }\end{array}$} \\
\hline & & & $\begin{array}{c}\text { однодоль- } \\
\text { них }\end{array}$ & $\begin{array}{c}\text { дводоль- } \\
\text { них }\end{array}$ & \\
\hline 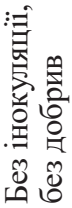 & $\begin{array}{l}\text { Контроль без гербіцидів, без прополювань } \\
\text { Контроль без гербіцидів } 3 \text { двома ручними } \\
\text { прополюваннями } \\
\text { Примекстра ТZ-Голд }(4,5 \text { л/га) } \\
\text { Зенкор }(0,4 \text { л/га) + Комманд }(0,2 \text { л/га) } \\
\text { Базагран }(2,5 \text { л/га) + Хармоні }(0,008 \text { кг/га) }\end{array}$ & $\begin{array}{c}68,6 / 0^{*} \\
88 \\
74 \\
70 \\
75\end{array}$ & $\begin{array}{r}28,6 / 0^{*} \\
\quad 88 \\
82 \\
72 \\
76\end{array}$ & $\begin{array}{c}36,8 / 0^{*} \\
89 \\
68 \\
67 \\
78\end{array}$ & $\begin{array}{r}3,2 / 0^{*} \\
87 \\
87 \\
79 \\
30\end{array}$ \\
\hline 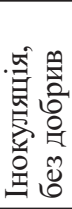 & $\begin{array}{l}\text { Контроль без гербіцидів, без прополювань } \\
\text { Контроль без гербіцидів } 3 \text { двома ручними } \\
\text { прополюваннями } \\
\text { Примекстра TZ-Голд }(4,5 \text { л/га) } \\
\text { Зенкор }(0,4 \text { л/га) + Комманд }(0,2 \text { л/га) } \\
\text { Базагран }(2,5 \text { л/га) + Хармоні }(0,008 \text { кг/га) }\end{array}$ & $\begin{array}{r}64,4 / 0 \\
83 \\
68 \\
64 \\
78\end{array}$ & $\begin{array}{r}29,6 / 0 \\
85 \\
82 \\
59 \\
77\end{array}$ & $\begin{array}{r}31,3 / 0 \\
80 \\
54 \\
72 \\
81\end{array}$ & $\begin{array}{l}3,5 / 0 \\
89 \\
76 \\
39 \\
56\end{array}$ \\
\hline 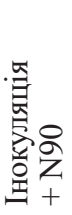 & $\begin{array}{l}\text { Контроль без гербіцидів, без прополювань } \\
\text { Контроль без гербіцидів } 3 \text { двома ручними } \\
\text { прополюваннями } \\
\text { Примекстра ТZ-Голд ( } 4,5 \text { л/га) } \\
\text { Зенкор }(0,4 \text { л/га) + Комманд }(0,2 \text { л/га) } \\
\text { Базагран }(2,5 \text { л/га)+Хармоні }(0,008 \text { кг/га) }\end{array}$ & $\begin{array}{c}66,6 / 0 \\
87 \\
62 \\
68 \\
77\end{array}$ & $\begin{array}{l}86 \\
80 \\
73 \\
76\end{array}$ & $\begin{array}{l}89 \\
48 \\
66 \\
80\end{array}$ & $\begin{array}{l}81 \\
53 \\
55 \\
56\end{array}$ \\
\hline
\end{tabular}

*чисельник - кількість бур'янів (шт./м2), знаменник - відсоток загибелі

ті дії гербіцидів є зниження сирої маси бур'янів. На контрольних варіантах без прополювань сира маса бур'янів перед збиранням врожаю коливалася в межах від 1650 г/ м $^{2}$ (без застосування інокуляції та без внесення мінерального азоту) до 2200 г/м² (за інокуляції та внесення додаткового азоту $\mathrm{N}_{90}$ ). Бакові суміші гербіцидів активно пригнічували ріст $\mathrm{i}$ розвиток бур'янів. Так, у разі внесення двокомпонентних сумішей Зенкор $(0,4$ л/га) + Комманд (0,2 л/га) та Базагран (2,5 л/га) + Хармоні (0,008 кг/га) сира маса бур'янів зменшувалася в середньому на $75 \%$. Близьким є результат діï Примекстра TZ-Голд (80 \%). Застосування 2 ручних прополювань знижувало сиру масу бур'янів перед збиранням на $94 \%$.

Якісне знищення бур'янів у посівах сої забезпечує високу врожайність культури. Дані таблиці 3 підтверджують високу біологічну й господарську ефективність дії препаратів (табл. 3), забезпечуючи достовірний приріст урожаю. Так, використання бакових сумішей гербіцидів в оптимальних агротехнічних дозах забезпечувало врожайність сої, більш ніж вдвічі вищу в порівнянні з контролем.

Вищий приріст врожайності забезпечило сумісне застосування трьох агротехнічних прийомів - ефективного захисту посівів від бур'янів, інокуляції посівного матеріалу та внесення азотних добрив. Середня врожайність за роки досліджень на варіантах із застосуванням бакової суміші гербіцидів Зенкору (0,4 л/га) і Комманду (0,2 л/га), інокуляції та мінерального азоту в дозі $\mathrm{N}_{90}$ досягла 4,2 т/га, що перевищує контрольний варіант без 


\section{2. Ефективність захисту посіві в сої від бур'янів перед збиранням культури (середнє за 2017 - 2018 рр.)}

\begin{tabular}{|c|c|c|c|c|c|c|}
\hline \multirow{3}{*}{ 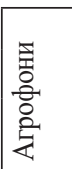 } & \multirow{3}{*}{ Варіанти застосування гербіцидів } & \multicolumn{5}{|c|}{ Загибель бур'янів, \% } \\
\hline & & \multirow{2}{*}{$\begin{array}{c}\text { Всього } \\
\text { бур'янів }\end{array}$} & \multicolumn{2}{|c|}{ однорічних } & \multirow{2}{*}{$\begin{array}{l}\text { багато- } \\
\text { річних }\end{array}$} & \multirow{2}{*}{$\begin{array}{c}\text { сира маса } \\
\text { бур'янів }\end{array}$} \\
\hline & & & $\begin{array}{c}\text { однодоль- } \\
\text { них }\end{array}$ & $\begin{array}{c}\text { дводоль- } \\
\text { них }\end{array}$ & & \\
\hline \multirow{5}{*}{ 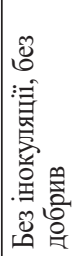 } & $\begin{array}{l}\text { Контроль без гербіцидів, без } \\
\text { прополювань } \\
\text { Контоль без гербішилів з лвома }\end{array}$ & $53,4 / 0$ & $24,6 / 0$ & $25,9 / 0$ & $2,9 / 0$ & $1650 / 0^{*}$ \\
\hline & ручними прополюваннями & 81 & 74 & 88 & 67 & 93 \\
\hline & Примекстра TZ-Голд (4,5 л/га) & 79 & 75 & 79 & 45 & 92 \\
\hline & Зенкор $(0,4$ л/га) + Комманд $(0,2$ л/га $)$ & 67 & 57 & 67 & 66 & 78 \\
\hline & $(0,008$ кг/га) & 65 & 45 & 81 & 86 & 74 \\
\hline \multirow{5}{*}{ 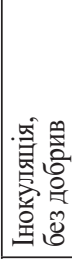 } & $\begin{array}{l}\text { Контроль без гербіцидів, без } \\
\text { прополювань } \\
\text { Контроль без гербішидів } 3 \text { двома }\end{array}$ & $45,2 / 0$ & $23,2 / 0$ & $20,0 / 0$ & $2,0 / 0$ & $2287 / 0^{*}$ \\
\hline & ручними прополюваннями & 87 & 88 & 86 & 82 & 97 \\
\hline & Піримекстра TZ-Голд (4,5 л/га) & 63 & 79 & 47 & 50 & 96 \\
\hline & $\begin{array}{l}\text { Зенкор (0,4 л/га) + Комманд }(0,2 \text { л/га) } \\
\text { Базагран (2,5 л/га)+Хармоні }(0,008\end{array}$ & 66 & 72 & 61 & 46 & 78 \\
\hline & кг/га) & 61 & 49 & 74 & 66 & 74 \\
\hline \multirow{5}{*}{ 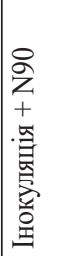 } & $\begin{array}{l}\text { Контроль без гербіцидів, без } \\
\text { прополювань }\end{array}$ & $40,1 / 0$ & $33,1 / 0$ & $19,0 / 0$ & $3,0 / 0$ & $2196,5 / 0^{*}$ \\
\hline & ручними прополюваннями & 88 & 92 & 91 & 78 & 96 \\
\hline & Примекстра TZ-Голд (4,5 л/га) & 73 & 93 & 57 & 78 & 74 \\
\hline & Зенкор (0,4 л/га) + Комманд $(0,2$ л/га) & 67 & 85 & 54 & 66 & 74 \\
\hline & $\mathrm{\kappa} / г \mathrm{a})$ & 61 & 68 & 74 & 83 & 75 \\
\hline
\end{tabular}

*чисельник - сира маса бур'янів $\left(\Gamma / \mathrm{M}^{2}\right)$, знаменник - відсоток загибелі

інокуляції, без добрив і без прополювань більше ніж на 300 \%. Водночас не відмічено негативного впливу екзогенного мінерального азоту на діяльність симбіотичних азотфіксаторів, залучених з інокуляцією.

За рівних умов видалення мінерального азоту з варіанту, де застосовано інокуляцію та бакову суміш Зенкору і Комманду, призвело до втрати урожайності відразу на 1 т/га.

Раціональне використання вказаних агроприйомів значно покращує якість зерна сої. Вміст білка на інокульованих посівах із внесенням азотних добрив та забезпеченням якісного контролю за бур'янами, досяг рівня 38 \%, що на 6,4 \% вище контролю.

\section{Висновки і перспективи.}

Отже, аналізуючи результати дворічних досліджень, можна зробити наступні висновки:

Високу технічну ефективність забезпечують бакові суміші грунтових (Зенкор (0,4 л/га) + Комманд (0,2 л/га)), так і післясходових (Базагран (2,5 л/га) + Хармоні (0,008 кг/га)) гербіцидів.

Більш суттєвий приріст урожаю сої забезпечує сумісне застосування гербіцидів, інокуляції посівного матеріалу та мінеральних азотних добрив.

Раціональне застосування трьох агротехнічних прийомів забезпечує значне покращення якості зерна сої, зокрема вмісту білка. 


\section{3. Урожайність та якість насіння сої залежно від рівня азотного живлення та ефективності захисту її посівів від бур'янів (середнс за 2017 - 2018 рр.)}

\begin{tabular}{|c|c|c|c|c|c|c|c|}
\hline \multirow{2}{*}{ 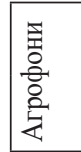 } & \multirow{2}{*}{ Варіанти застосування гербіцидів } & \multicolumn{2}{|c|}{$\begin{array}{c}\text { Урожайність сої, } \\
\text { т/га }\end{array}$} & \multirow{2}{*}{ 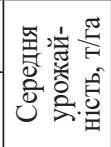 } & \multicolumn{2}{|c|}{$\begin{array}{l}\text { Приріст } \\
\text { урожаю }\end{array}$} & \multirow{2}{*}{$\begin{array}{c}\text { Вміст } \\
\text { білка, } \\
\%\end{array}$} \\
\hline & & $2017 \mathrm{p}$. & $2018 \mathrm{p}$ & & $\mathrm{T} / \mathrm{ra}$ & $\%$ & \\
\hline 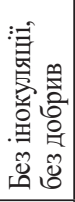 & $\begin{array}{l}\text { Контроль без гербіцидів, без прополювань } \\
\text { Контроль без гербіцидів } 3 \text { двома ручними } \\
\text { прополюваннями } \\
\text { Примекстра TZ-Голд (4,5 л/га) } \\
\text { Зенкор }(0,4 \text { л/га) + Комманд }(0,2 \text { л/га) } \\
\text { Базагран }(2,5 \text { л/га) + Хармоні }(0,008 \text { кг/га) }\end{array}$ & $\begin{array}{l}1,43 \\
0,93 \\
1,23 \\
1,39 \\
\end{array}$ & $\begin{array}{l}2,92 \\
3,03 \\
3,34 \\
3,41\end{array}$ & $\begin{array}{l}2,18 \\
1,98 \\
2,29 \\
2,40 \\
\end{array}$ & $\begin{array}{l}0,95 \\
0,75 \\
1,06 \\
1,17 \\
\end{array}$ & $\begin{array}{l}77 \\
61 \\
86 \\
95 \\
\end{array}$ & $\begin{array}{l}30,50 \\
33,80 \\
33,05 \\
32,60\end{array}$ \\
\hline 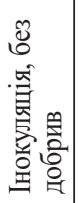 & $\begin{array}{l}\text { Контроль без гербіцидів, без прополювань } \\
\text { Контроль без гербіцидів } 3 \text { двома ручними } \\
\text { прополюваннями } \\
\text { Примекстра TZ-Голд (4,5 л/га) } \\
\text { Зенкор }(0,4 \text { л/га) + Комманд }(0,2 \text { л/га) } \\
\text { Базагран }(2,5 \text { л/га) + Хармоні }(0,008 \text { кг/га) }\end{array}$ & $\begin{array}{l}0,73 \\
1,54 \\
0,96 \\
1,17 \\
1,53\end{array}$ & $\begin{array}{l}4,56 \\
4,30 \\
4,99 \\
5,03\end{array}$ & $\begin{array}{l}3,05 \\
2,63 \\
3,08 \\
3,28\end{array}$ & $\begin{array}{l}1,21 \\
0,79 \\
1,24 \\
1,44\end{array}$ & $\begin{array}{l}66 \\
43 \\
67 \\
78\end{array}$ & $\begin{array}{l}37,60 \\
37,25 \\
38,30 \\
39,70\end{array}$ \\
\hline 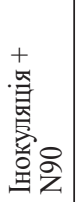 & $\begin{array}{l}\text { Контроль без гербіцидів, без прополювань } \\
\text { Контроль без гербіцидів } 3 \text { двома ручними } \\
\text { прополюваннями } \\
\text { Примекстра ТZ-Голд }(4,5 \text { л/га) } \\
\text { Зенкор }(0,4 \text { л/га) + Комманд }(0,2 \text { л/га) } \\
\text { Базагран }(2,5 \text { л/га) + Хармоні }(0,008 \text { кг/га) }\end{array}$ & $\begin{array}{l}2,44 \\
1,69 \\
2,39 \\
2,48\end{array}$ & $\begin{array}{l}5,52 \\
5,33 \\
5,94 \\
5,54\end{array}$ & $\begin{array}{l}3,98 \\
3,51 \\
4,17 \\
4,01\end{array}$ & $\begin{array}{l}1,66 \\
1,19 \\
1,85 \\
1,69\end{array}$ & $\begin{array}{l}72 \\
51 \\
80 \\
73\end{array}$ & $\begin{array}{l}37,40 \\
37,60 \\
38,05 \\
38,00\end{array}$ \\
\hline & $\begin{array}{l}\text { для фактора А } \\
\text { для фактора В }\end{array}$ & $\begin{array}{l}1,40 \\
1,69\end{array}$ & $\begin{array}{l}3,53 \\
4,30\end{array}$ & $\begin{array}{l}2,47 \\
3,00\end{array}$ & $\begin{array}{l}- \\
-\end{array}$ & - & $\begin{array}{l}0,21 \\
0,25\end{array}$ \\
\hline
\end{tabular}

\section{References}

1. Hutianskyi R.A. (2013). Efektyvnist poiednannia triokh pisliaskhodovykh herbitsydiv u posivakh soi [Effectivity of combination of three post-emergence herbicides in soybean crops]. Scientific and technical bulletin of Institute of oil plants of NAAS, 18, 72-78.

2. Shepilova T.P. (2016). Efektyvnist dii herbitsydiv v posivakh soi [Effectivity of herbicide action in soybean crops]. Messenger of Uhman National University of gardening, 1, 7-9.

3. Hutianskyi R.A. (2008). Efektyvnist antyburianovykh pryiomiv. Dohliad za posivamy soi pry kombinovanomu zastosuvanni ahrotekhnichnykh ta khimichnykh zakhodiv [Effectivity of anti-weed measures. Care of soybean crops at combined applying of agrotechnical and chemical measures]. Quarantine and protection of plants, 7, 22-24.
4. Huralchuk Zh.Z., Sorokina S.I., Rodzevych O.P., Morderer Ye.Yu. (2012). Azotfiksuvalna aktyvnist soi za sumisnoho zastosuvannia herbitsydiv i mikrodobryv [Soybean nitrogen-fixing activity at combined application of herbicides with microfertilizers]. Scientific notes of Tauride V. Vernadsky National University. Series: biology, chemistry. 25(64), 4, 34-41.

5. Rekomendacii po primeneniyu Rizotorfina $v$ tehnologii vozdelyvaniya bobovyh kul'tur [Recommendations about applying of Risotorphine in the technology of production of legume cultivars] (1987). Kyiv, Ukraine: Yield, $21 \mathrm{p}$.

6. Datsenko V.K., Malichenko S.M., Berehovenko S.K., Kots S.Ya. (2001). Novi ahrokhimikaty yak zasib pidvyshchennia azotfiksuvalnoi zdatnosti soi [New agrochemicals as a way of increment of soybean nitrogen-fixation facility]. Collection "Plant ontogenesis, bi- 
ological fixation of molecular nitrogen and nitrogenous metabolism", Ternopil, 69-72.

7. Pyshchur I.M., Kanivets V.I., Larchenko I.V. (2014).Vplyv suchasnykh herbitsydiv na formuvannia soievo-ryzobialnoho symbiozu za vykorystannia mikrobnoho preparatu Ryzohuminu [Influence of modern herbicides on soybean-rhizobial symbiosis formation at use of a bacterium drug Rhyzogumin]. Agricultural microbiology, 8, 100-108.

8. Kulyk M.F., Zhmud O.V., Babych A.O., Zasukha T.V., Obertiukh Yu.V., Kulyk Ya.M., Zelinska N.B. (2010). Do pytannia biolohichno aktyvnykh rechovyn soi [To an issue of soybean biologically active substances]. Messenger of an agrarian science, 10, 28-33.
9. Zherebko V.M., Zherebko Yu.V., Chernega T.A. (2000). Effektivnost' regulirovaniya urovnya zasoryonnosti posevov soi v Lesostepi Ukrainy [Effectivity of regulation of a soybean crop weediness standard in the Forest-Steppe of Ukraine]. State and development of herbology on the threshold of the 21th century. Materials of the second All-Russian scientific and manufacturing consultation. Golitsyno, Russian, 114-118.

10. Zherebko V.M. (2015). The impact of weeds and care of crops qualitative indicators of soybean crop. Scientific reports of National University of Life and Environmental Sciences of Ukraine, 7. Available at: http:// nbuv.gov.ua/UJRN/Nd_2015_7_11.

\section{V.M. Zherebko, O.V. Dykun, M.O. Dykun (2019). INFLUENCE OF NITROGEN NUTRITION AND WEED PROTECTION OF CROPS ON PRODUCTIVITY OF SOYBEANS IN THE RIGHT-BANK FOREST-STEPPE OF UKRAINE. PLANT AND SOIL SCIENCE, 10(3):} 55-62. https://doi.org/10.31548/agr2019.03.055

Abstract. In this article results of two years old researches of joint influence of chemical protection of crops from weeds, nitrogen mineral fertilizers and inoculation of sowing material on productivity and quality of soybean harvests in the Right-bank Forest-Steppe of Ukraine were analyzed.

Field experiments in the course of from 2017 to 2018 were conducted in a stationary crop rotation of the laboratory of selection and seed production of the separated subdivision of National University of Life and Environmental Sciences of Ukraine "Agronomic Research Station" in a village Pshenychne of Vasylkivsky district of Kyiv region. It was found out that tank mixtures of herbicides provided high-level technical efficiency under conditions of a mixed type of weediness in both soil - Zenkor $(0,4 \mathrm{l} / \mathrm{ha})+$ Kommand $(0,2 \mathrm{l} / \mathrm{ha})$ and post-emergence ones - Basagran $(2,5 \mathrm{l} / \mathrm{ha})+$ Harmony $(0,008 \mathrm{~kg} / \mathrm{ha})$. In the specified doses, two-component mixtures of herbicides lowered a total number of monocot and dicotyledonous weeds by $41-78$ percent on the 30th day after introduction and by 61-67 percent before harvesting, and lowered crude weight of all the weeds almost by 80 percent. It was noticed that effective control of weediness of crops with a mixture of drugs Zenkor and Kommand, preliminary inoculation and introduction of nitrogen mineral fertilizers in a dose N9O, promoted increment of plant productivity and formation of higher yield. Its veracious increase in relation to a control without inoculation, fertilizers and chemical weeding achieved almost 3 tons per hectare or closely to 300 percent on these variants. At the same time, negative influence of endogenous mineral nitrogen and an herbicide background on processes of biologic nitrogen fixation in soil wasn't revealed.

Results of researches show positive influence of rational use of agrotechnical measures listed above on improvement of soybean harvest quality, in particular on increment of protein contents in grains by 6,4 percent.

Keywords: soybeans, soil and post-emergence herbicides, technical effectivity, tank mixtures, inoculation, nitrogen fertilizers, effectivity of application 